\title{
Reindriftssamer har \\ pleie- og omsorgsbehov i to kommuner
}

For at reindriftssamer med behov for pleie- og omsorgstjenester skal få god oppfølging, må sommerhjemkommunen og vinterhjemkommunen samhandle bedre.

\section{June Brita Eira}

Universitetslektor

Institutt for helse- og omsorgsfag, UiT- Norges Arktiske Universitet

\section{Grete Mehus}

Førsteamanuensis

Institutt for helse- og omsorgsfag, UiT - Norges arktiske universitet

Hjemmetjeneste

Kultur

Sykepleien 2022;110(88154):e-88154

DOI: 10.4220/Sykepleiens.2022.88154

\section{Hovedbudskap}

Hensikten med artikkelen er å belyse en kommunes erfaringer med å samhandle og vurdere behov for pleie- og omsorgstjenester for samiske pasienter som tilhører reindriften og kommer til sommerhjemmet. Dette er en viktig problemstilling med tanke på reindriftssamenes rett til likeverdige helsetjenester uavhengig av hvor de oppholder seg. 
Samiske storfamilier drar med reinflokken mellom to bostedskommuner vinterhjemmet og sommerhjemmet - om våren og om høsten. Familiemedlemmer med pleie- og omsorgstjenester (PLO-tjenester) kan oppleve å få ulik vurdering av tjenestebehovet sitt i de to kommunene.

Dermed får de kanskje ikke dekket det reelle tjenestebehovet i sommerhjemmet sitt. Hva som kan være årsaken til dette, skal vi diskutere i denne artikkelen.

Samene er anerkjent som Norges urfolk og har derfor stadfestet særlige rettigheter til å bevare og videreutvikle sin kultur. Myndighetene har plikt til å treffe tiltak for å støtte dette gjennom ILO-konvensjon nr. 169 (1) og Grunnloven § 108, kalt sameparagrafen (2).

Det gjelder også retten til å opprettholde bo- og livsform. Litt over 3000 av den samiske befolkningen er tilknyttet tradisjonell reindrift og kjøttproduksjon (3).

\section{To hjem er ikke alltid et primær- og et sekundærhjem}

Befolkningen i Norge har ifølge helse- og omsorgstjenesteloven rett til forsvarlig, helhetlig og koordinert helsetilbud der de oppholder seg (4).

Reindriftssamene klassifiserer ikke vinterhjemmet og sommerhjemmet som primær- og sekundærbolig, slik offentlig forvaltning legger opp til $(5,6)$, men som to likeverdige hjem.

Det norske velferdssystemet tar ikke automatisk høyde for at brukere av tjenestene lever innenfor et etablert system med to hjem. Dette medfører utfordringer med at pasienten har to pleie- og omsorgsvedtak, ett fra hver kommune.

\section{Reindriftsfamilier har en halvnomadisk livsførsel}

Sosiologen og filosofen Habermas skriver at kommunikativ handling springer ut fra to ulike perspektiver, som han kaller livsverden og systemverden (7). Disse to verdenene har ulike verdier, forforståelser og regler for handlingsrom.

På den ene siden er for eksempel reindriftssamene, som i sitt livsverdenperspektiv definerer et hjem innenfor rammen av sin halvnomadiske boform med to hjem der storfamilien er samlet.

På den andre siden er det offentlige forvaltningssystemet, som beskriver byråkratisk hva som betegnes som primær- og sekundærhjem, med vilkår som er skapt innenfor en systemverden $(5,6)$. 
På den måten kan vi si at systemverdenen invaderer livsverdenperspektivet, og det er innenfor denne tosidige forståelsesrammen at søknader om pleie- og omsorgstjenester for reindriftssamer forvaltes.

Det er nødvendig at helsebyråkratiet, representert via systemperspektivet, har forståelse for etablerte tohjemsystemer for å sikre at reindriftssamene får likeverdige tjenester både i vinterhjemmet og sommerhjemmet.

\section{Samhandlingsreformen stiller krav til kommunene}

Samhandlingsreformen krever at det skal være samhandling mellom spesialisthelsetjenesten og kommunene, interkommunalt samarbeid og samarbeid internt $\mathrm{i}$ kommunene på tvers av virksomhetene.

Helse- og omsorgsdepartementet innførte elektronisk pasientjournal med mål om tverrfaglig elektronisk kommunikasjon på tvers av spesialisthelsetjenester og kommunehelsetjenesten (8). Likevel mangler enkelte dataprogrammer muligheten til å kommunisere om pasienter generelt både innad i kommunen og mellom kommuner med felles pasienter $(9,10)$.

Helse- og omsorgstjenesteloven garanterer helsehjelp til pasienter som oppholder seg i kommunene, men forplikter ikke kommunene til samhandling på tvers av grensene (4). Det er en utfordring når helsetjenestelovverket skal forvaltes, siden kommunene som pleie- og omsorgsleverandører må ha et tilstrekkelig samarbeid om tjenestene som gis.

\section{Det kan være konkurranse om helsepersonell}

I litteraturs $\emptyset$ kene finner vi ikke studier om hjemmesykepleiens erfaringer med å ta imot reindriftssamer med pleie- og omsorgsbehov i sommerhjemmet.

Litteraturs $\emptyset$ kene vi har gjort om samhandling, viser at det har vært flere norske studier de senere årene som handler om samhandling mellom kommunehelsetjenesten og spesialisthelsetjeneste (9-11).

En av disse studiene evaluerer hvordan kommunene har innrettet seg etter de kravene som settes i samhandlingsreformen (9). Studien rapporterer at interkommunalt samarbeid handler om å rette seg mot hva som tjener den enkelte kommune best, å beskytte egne tjenester samt konkurranse om helsepersonell.

\section{Det finnes gjensidige, stereotype oppfatninger}


En annen studie, som handler om hvordan samiske og ikke-samiske, formelle og uformelle omsorgsgivere samarbeider, påpeker at de har gjensidige, stereotype oppfatninger av hverandre, og at det krever tid og gjensidig tillit til å bygge opp gode samarbeidsformer i et pleieforhold (12).

En oversiktsstudie unders $\varnothing$ ker samhandlingsutfordringer og hvilke kommunikasjonsformer som ble benyttet i samhandling mellom helseprofesjonene (13).

Den konkluderer med at det er behov for avklaring om hvilken informasjon som skal være med i en informasjonsutveksling, og at det er nødvendig med bedre samhandling mellom kommuner og spesialisthelsetjenesten.

\section{Fremgangsmåte for studien}

Denne artikkelen er et masterbidrag i NFR-prosjekt (287301) «Coming of Age in Indigenous Communities» og bygger på data fra et fokusgruppeintervju av tre tjenesteutøvere med gjennomsnittlig arbeidserfaring på 21 år med PLO-tjenester til reindriftssamer som har to hjem.

Vi gjennomførte intervjuet i oktober 2019 på deltakernes arbeidsplass. Det varte i cirka 70 minutter. Vi transkriberte og analyserte intervjuet og tematiserte innholdet. Intervjuene oppsummeres under to hovedtemaer: «Manglende samhandling» og «Balanse mellom reelt tjenestetilbud og forventninger».

\section{Manglende samhandling}

En sentral tematikk vi diskuterte i intervjuet, var samhandlingens viktige funksjon, som blant annet skal være opplysende, forebyggende og samlende i et pasientforløp.

Det kom frem at det er vesentlige mangler på systemnivå, slik som manglende samhandling mellom: a) tjenesteutøvere i de to kommunene og b) pasienten og pasientens pårørende og hjemmetjenesten.

Hjemmesykepleien i vinterhjemkommunen ringte sjelden og meldte om at pasientene kom, selv om deres opphold var av opptil seks måneders varighet. Dette var uheldig i planleggingen av kommunens PLO-tilbud om sommeren på grunn av ferieavvikling, som medførte nedbemanning.

\section{«Hjemmesykepleien i vinterhjemkommunen ringte sjelden og meldte om at pasientene kom.»}


Sykepleierne fortalte at de kjente til de faste sommerpasientene i reindriftsfamiliene. Pasientene hadde oftest behov for de samme tjenestene i sommerhjemmet som i vinterhjemmet, slik som medikamenthåndtering, å stå opp, sårstell, kroppsstell og dusjing.

De fortalte at hvis pasienten tok kontakt på forhånd, var det som oftest et familiemedlem som ringte og ordnet kontakt med kommunen. Pårørende var ikke alltid informert om hvilke pleie- og omsorgstjenester pasienten hadde i vinterkommunen.

Datoen for ankomsten til sommerhjemmet var vanskelig å forutsi helt presist fordi vær- og føreforhold og reinflokken bestemte fremdriften i flyttingen.

\section{Kommunikasjonen ble endret etter samhandlingsreformen}

Deltakerne i intervjuet fortalte om hvordan informasjonsutvekslingen om felles pasienter hadde endret seg etter samhandlingsreformens innføring i 2012. Tidligere skrev eller ringte tjenesteut $\varnothing$ vere i vinterhjemkommunen for å informere om pasientenes behov før de reiste til sommerhjemmet.

Samhandlingsreformens krav til elektronisk kommunikasjon gjennom IKT-verktøy, i tillegg til manglende lovpålegg om interkommunal samhandling i helse- og omsorgstjenesteloven (4), kan ha medført at disse kommunene sluttet å snakke sammen slik de hadde gjort tidligere. Deltakerne sa at det ikke var tvil om at elektronisk meldingsutveksling ville vært en ideell måte å samhandle på i dag.

En deltaker sa at det var et presserende behov for å definere ansvarsforholdet angående informasjonsplikten om pasientens tjenestebehov. For dem hadde det vært naturlig å sørge for at pasienter som reiste, fikk dekket sitt hjelpebehov på stedet de dro til.

På den andre siden sa de at de ikke rapporterte tilbake til vinterhjemkommunen om endringer $\mathrm{i}$ helsetilstand og funksjonsnivå hos de faste sommerhjempasientene når de dro tilbake til vinterhjemmet. Mangelen på kommunikasjon om felles pasienter gikk dermed begge veier.

\section{Balanse mellom reelt tjenestetilbud og forventninger}

Deltakerne beskrev at det var utfordringer med fasilitetene i pasientens sommerhjem. Det var trange arbeidsforhold der de utførte stell i små rom og sårskift i lavvo.

En tjenesteutøver beskrev det slik mens hun smilte: «Enkle sårskift i lavvo er en eksotisk oppgave, til tross for at det er vondt å sitte på knærne og ta et sårstell.» 
Deltakerne måtte finne kreative løsninger på grunn av hjemmets utforming og manglende hjelpemidler. Ofte tok de med seg egne hjelpemidler som dusjstol og utstyr til stell, eller de tok med pasientene til sykehjemmet for at de skulle få dusje hvis de ikke hadde varmt vann og dusj i sommerhjemmet.

\section{Kommunen og pasientene kan ha ulike ønsker}

Sykepleierne beskrev at det kunne være manglende balanse mellom de tjenestene de reelt kunne tilby, og pårørendes forventninger. Noen pasienter $\varnothing$ nsket for eksempel at helsepersonellet skulle sørge for daglig morgenstell i lavvoen.

Deltakerne sa at det ble for tungt å sitte på knærne og ta et fullt kroppsstell av pasientene, og de løste det ved å stelle dem inne i sommerhuset. Pasientene kunne også ha med seg medisindosetter fra vinterkommunen.

\section{«Noen pasienter ønsket at helsepersonellet skulle sørge for daglig morgenstell i lavvoen.»}

Deltakerne fortalte at det kunne oppstå uenigheter mellom kommunen og pasientene og de pårørende om hvem som skulle sørge for fri, trygg ferdsel langs kjerre- og fjellveier til sommerhjemmet.

Alle pleie- og omsorgsvedtak ble utformet med en generell anbefaling fra Arbeidstilsynet om å ta forbehold angående fremkommelighet til husstanden. Gjennom dette ble pasientene forpliktet til å sørge for atkomst til boligen.

Deltakerne diskuterte hvordan de selv kunne ta ansvaret ved å vurdere pasientsituasjonen bedre og kontakte hjemmesykepleien i vinterhjemkommunen på forhånd før de lagde PLO-vedtak.

Med god forhåndskommunikasjon kunne pasientens og de pårørendes forventninger og det reelle tjenestetilbudet ha vært avklart før de ankom sommerhjemkommunen.

\section{Det er samhandlingsutfordringer mellom partene}

Det er helt eller delvis manglende samhandling om pleiebehov og fasilitering hos de involverte partene. Dermed er det vanskelig å planlegge omsorgen og avklare gjensidige forventninger.

Det kan se ut som at det er et generelt problem og et savn at pasienter som kommer til denne kommunen, melder fra for sent, og at de ikke informerer på forhånd om tjenestebehovet sitt. 
Kommunene samhandler heller ikke om felles pasienter, og det kan se ut som om initiativet til samhandlingen må komme fra pårørende og pasienten.

Pårørende kontakter kommunen på vegne av pasienten idet de ankommer. Grunnen til sen kontakt kan være tidsaspektet i reinflyttingen samt at vær- og føreforhold bestemmer ankomsten. Dette fenomenet kan være vanskelig å forholde seg til i systemverdenen.

\section{Reindriftssamer har ikke en presis ankomstdato}

I reindriftssamers livsverden er det en selvfølge at de ikke kan angi en presis ankomstdato og angi lengden på sommeroppholdet fordi det er utenfor deres kontroll. Reinflokkens instinkter styrer denne tiden. Det kan også være at pasienten eller de pårørende opplever en språkbarriere mot å kontakte hjelpeapparatet utenfor sin egen samiskspråklige kommune (12, 14-16).

De kan også tenke at de vil bli «berget» når de kommer til sommerkommunen der de har storfamilien rundt seg, og kanskje har de med seg ferdige medisindosetter fra vinterhjemkommunen (17-20).

\section{«De kan også tenke at de vil bli 'berget' når de kommer til sommerkommunen der de har storfamilien rundt seg.»}

Tjenesteutøverne i vinterhjemkommunen burde hatt en dialog med sommerhjemkommunen på vegne av og i samråd med pasienten før pasienten reiste. Da kunne de ha diskutert hvordan tjenestebehovet kunne løses i sommerhjemmet, og tjenestene kunne ha vært på plass i sommerkommunen ved pasientens ankomst.

Manglende samhandling mellom partene kan gi motstridende forventninger til hvilke tjenester som faktisk kan ytes i sommerhjemkommunen. Sykepleierne vi intervjuet, fremsto som $1 \varnothing$ sningsorienterte samtidig som de satte grenser for hva de faktisk kunne klare å gjennomføre.

\section{Det kan være utfordringer med fremkommelighet}

PLO-vedtakene med generelle atkomstforbehold, som er anbefalt av Arbeidstilsynet, kan bli en barriere for å yte hjelp. Veistandarden til pasientens sommerhjem, som nesten alltid er på fjellet, et stykke fra en hovedvei eller nede ved sjøen, er ikke alltid gunstig, men godt nok med tanke på reindriftssamenes behov. 
Om våren og høsten kan snø- og tineforholdene være til hinder og skape vanskelige kjøreforhold, noe som er dagligdagse utfordringer i livsformen til reindriftssamene og helt normalt i avsidesliggende områder.

I andre samiske kommuner i nord har hjemmesykepleien benyttet ATV, snøscooter, ski eller båt for å gjennomføre PLO-vedtakene til pasienter som bor litt utilgjengelig, samt at deres tjenestebiler tilpasses fjellforhold.

Utfordringer med fremkommelighet kan også løses ved at hjemmesykepleien avtaler å bli hentet av pårørende med ATV, eller at hjemmesykepleien holder slike kjøretøy selv.

\section{Interkommunal samhandling fungerer ikke godt nok}

Da kommunene innførte elektronisk samhandling i 2012, fikk de IKT-verktøy som ikke fungerte interkommunalt. Det ser ut til at interkommunal samhandling har blitt neglisjert etter innføringen av samhandlingsreformen (13), til tross for at samhandlingens hovedhensikt er å sikre gode pasientforløp (8).

Tjenesteut Øverne i sommer- og vinterhjemkommunene kunne ha tatt initiativet til å opprettholde giensidig kontakt via telefon på vegne av pasientene som de vet flytter årlig, for å avklare eventuelle endringer i tjenestebehov og forventninger til hverandre.

\section{«Det ser ut til at interkommunal samhandling har blitt neglisjert etter innføringen av samhandlingsreformen.»}

Der samhandlingsreformen omtaler «Særskilte utfordringer for den samiske befolkningen», tar den ikke høyde for at reindriftssamene kan ha sesongavhengig bostedsadresse i to kommuner, og hvilke tjenesteutfordringer dette kan gi (8, s. 1617).

Når ikke samhandlingskrav om felles pasienter mellom kommuner er lovfestet (8), og når lovpålegget angående hensynet til effektive elektroniske journal- og informasjonssystemer er utydelig (4), kan kommunene velge bort samhandling.

\section{Et pleie- og omsorgsvedtak bør følge pasienten}

Man kan trekke paralleller mellom halvnomadisk livsførsel og bruk av offentlige helsetjenester til det Habermas beskriver som innholdet i henholdsvis livsverdenen og systemverdenen (7). 
Livsverdenen representerer en forståelse av hverdagen og handlemåter som en kommuniserer ut fra, og ikke nødvendigvis problematiserer, slik som å dra til sommerhjemmet uten å melde fra om ankomsten.

Dette er en motsetning til systemverdenens forventninger, som er representert gjennom lovverk, regler og skjønn for hvordan pasientoverflyttinger skal organiseres gjennom en ny vurdering av pleie- og omsorgsbehov.

Systemverdenen representerer en organisert virkelighet som kanskje ikke imøtekommer reindriftssamenes forståelse i et livsverdenperspektiv. Et pleie- og omsorgsvedtak bør derfor være pasientens vedtak og følge pasienten.

A flytte mellom to kommuner fordrer aktiv samhandling mellom pasienten, de pårørende og kommunene, slik at tjenesten er forberedt på hvem som kommer, og hva deres reelle pleie- og omsorgstjenestebehov er.

\section{Konklusjon}

Denne artikkelen belyser hvilke samhandlingsutfordringer som oppstår når reindriftssamer med pleie- og omsorgsbehov ankommer sommerhjemkommunen og ber om tjenester uten at kommunene har hatt kommunikasjon om det.

Funnene viser at det er manglende samhandling mellom vinter- og sommerhjemkommunen på både individ- og systemnivå. Det er systemsvikt når IKT-systemene ikke fungerer interkommunalt. På tross av manglende samhandling mellom sommer- og vinterhjemkommunene ser det ut til at de strekker seg langt for å imøtekomme tjenestebehovet hos pasientene som ankommer.

Helselovverk og forskrifter bør utformes på en måte som dekker reindriftssamers behov for helsetjenester i tråd med ILO-konvensjonen nr. 169 og helselovverket, der henholdsvis retten til å opprettholde bo- og driftsform og retten til likeverdige helsetjenester der en bor, er stadfestet.

\section{Referanser}

1. ILO-konvensjon nr. 169 om urfolk og stammefolk i selvstendige stater. Oslo: Kommunal- og distriktsdepartementet; 1990. Tilgjengelig fra:

https://www.regjeringen.no/no/tema/urfolk-og-

minoriteter/samepolitikk/midtspalte/ilokonvensjon-nr-169-om-urbefolkningero/id451312/ (nedlastet 08.11.2021).

2. Kongeriket Norges Grunnlov (Grunnloven). Tilgjengelig fra: https://lovdata.no/dokument/NL/lov/1814-05-17?q=grunnloven (nedlastet 14.05.2020). 
3. Landbruks- og matdepartementet. Reindrift. Oslo: Landbruks- og matdepartementet; 2019.

4. Lov 24. juni $2011 \mathrm{nr} .30$ om kommunale helse- og omsorgstjenester (helse- og omsorgstjenesteloven). Tilgjengelig fra: https://lovdata.no/dokument/NL/lov/201106-24-30 (nedlastet 08.11.2021).

5. Skatteetaten. Skille mellom primærbolig og sekundærbolig. Oslo:

Skatteetaten; 2018. Tilgjengelig fra: https://www.skatteetaten.no/sok/? q=prim\%C3\%A6rbolig\%20og\%2osekund\%C3\%A6rbolig\&se=16614 (nedlastet 08.11.2021).

6. Lov 9. september $2016 \mathrm{nr} .88 \mathrm{om}$ folkeregistrering (folkeregisterloven). Tilgjengelig fra: https://lovdata.no/dokument/NL/lov/2016-12-09-88? q=lov\%20om\%2ofolkeregistrering (nedlastet 08.11.2021)

7. Habermas J. The theory of communicative action: 2: lifeworld and system: a critique of functionalist reason. Boston: Bacon Press; 1987.

8. Forskrift 1. juli 2015 om standarder og nasjonale e-helseløsninger (forskrift 22. desember 2021 om endring i forskrift om standarder og nasjonale ehelseløsninger). Oslo: Helse- og omsorgsdepartementet; 2015.

9. Aarseth T, Bachmann KE, Gjerde I, Skrove GK. Mot samhandlingskommunen? Om endringer i kommunenes eksterne og interne relasjoner i møte med en nasjonal helsereform. Nordiske organisasjonsstudier. 2015;17(3):24.

10. Kassah BLL, Tønnessen S. Samhandling i kommunale helse- og omsorgstjenester - en studie av hjemmesykepleieres erfaringer. Tidsskrift for velferdsforskning. 2016;19(4):342-58. DOI: 10.18261/issn.2464-3076-2016-04-04

11. Tønnessen S, Kassah BLL, Tingvoll W-A. Hjemmesykepleierne i denne studien opplever organisatorisk skjevfordeling av makt. Sykepleien. 2016;11(1):8. DOI: $\underline{10.4220 / \text { Sykepleienf.2016.56496 }}$

12. Larsen LS, Normann HK, Hamran T. Collaboration between Sami and nonSami formal and family caregivers in rural municipalities. Ethnic and Racial Studies. 2016;39(5):821-39. DOI: 10.1080/01419870.2015.1080382

13. Vik E. Helseprofesjoners samhandling - en litteraturstudie. Tidsskrift for velferdsforskning. 2018;21(2):119-47. DOI: 10.18261/issn.2464-3076-2018-02-03 
14. Mehus G, Bongo BA, Engenes JI, Moffitt P. Exploring why and how encounters with the Norwegian healthcare system can be considered culturally unsafe by North-Sami speaking patients and relatives: a qualitative study based on 11 interviews. International Journal of Circumpolar Health. 2019;78(1). DOI: 10.1080/22423982.2019.1612703

15. Mehus G, Bongo BA, Moffitt P. Important factors when communicating with Sami patients about health, illness and care issues. Nordisk sygeplejeforskning. 2018;8(4):13.

16. Engenes JI, Sivertsen N, Bongo BA, Mehus G. Sámi language in Norwegian health care: 'He speaks good enough Norwegian, I don't see why he needs an interpreter'. Scandinavian Journal of Caring Sciences. 2021;1-10. DOI: $10.1111 / \operatorname{scs} .12986$

17. Aikio A. Olmmošhan gal birge: áššit mat ovddidit birgema. Kárášjohka: Č́lliidLágadus; 2010.

18. Andersen KB. Å berges: erfaringer om bedringsprosesser ved alvorlige psykiske lidelser i sjøsamisk område. I: Silviken A, Stordahl V, red. Samisk psykisk helsevern - nye landskaper, kjente steder og skjulte utfordringer. Karasjok: Forfatternes Forlag; 2010. s. 226-52.

19. Nymo R. Ikke bekymre deg for morgendagen, det ordner seg skal du se! I: Austad A, Bogo L, Leenderts TA, Stifoss-Hanssen H, Thomassen M, red. Lidelse, mening og livssyn. Bergen: Fagbokforlaget; 2020. s. 233-251.

20. Javo C. Verdier, livssyn og tro i samisk kulturelle tradisjon - erfaringer og refleksjoner fra klinisk praksis. I: Austad A, Bogo L, Leenderts TA, Stifoss-Hanssen H, red. Lidelse, mening og livssyn. Bergen: Fagbokforlaget; 2020. s. 253-263. 